\title{
Analisis Perbedaan Relevansi Nilai Informasi Akuntansi Sebelum Dan Sesudah PSAK Konvergensi IFRS (Studi Pada Perusahaan Sektor Perbankan Yang Terdaftar di Bursa Efek Indonesia Periode 2009-2014)
}

\author{
Berta Agus Petra SE, M.Si \\ Fakultas Ekonomi Universitas Putra Indonesia "YPTK" Padang \\ Email: agusberta885@gmail.com
}

\begin{abstract}
Abstrak
Penelitian ini bertujuan untuk memberikan bukti empiris tentang perbedaan relevansi nilai informasi akuntansi sebelum dan sesudah menggunakan PSAK konvergensi IFRS. Objek penelitian adalah perusahaan perbankan yang terdaftar di Bursa Efek Indonesia (BEI) selama 6 periode (2009-2014). Penelitian ini menggunakan teknik purposive sampling dalam pengumpulan data. Data yang digunakan merupakan data sekunder yang dikumpulkan dari www.idx.co.id, www.yahoofinance.com, Indonesian Capital Market Directory (ICMD) serta sumber lain yang relevan dengan penelitian ini. Data dianalisis menggunakan persamaan regresi linear berganda dan Paired sample t-test sebagai pengujian hipotesis. Hasil penelitian ini menunjukkan ada perbedan relevansi nilai informasi akuntansi sebelum dan sesudah konvergensi IFRS.
\end{abstract}

kata kunci $\quad$ : Relevansi Nilai Informasi Akuntansi, PSAK Konvergensi IFRS

\section{Pendahuluan}

Pada akhir tahun 2015, ASEAN Economic Community (AEC) atau lebih dikenal dengan Masyarakat Ekonomi ASEAN (MEA) mulai diterapkan. Bakhri (2015) menjelaskan penerapan MEA menurut Deklarasi Cetak Biru Komunitas Ekonomi ASEAN merupakan pasar tunggal dan berbasis produksi yang memiliki lima elemen yaitu aliran bebas barang, aliran bebas jasa, aliran bebas investasi, aliran modal yang lebih bebas, serta aliran tenaga kerja yang terampil di kawasan ASEAN.

Peluang yang dapat dimanfaatkan oleh perusahaan-perusahaan yang ada di Indonesia dengan hadirnya MEA ini salah satunya adalah, melakukan investasi serta membuka cabang perusahaannya di negara-negara kawasan ASEAN. Untuk mempermudah hal ini dapat terjadi, standar pencatatan pelaporan keuangannya harus menyesuaikan dengan standar pelaporan keuangan negara tujuannya. Dengan adanya tuntutan penerapan MEA seperti ini, maka dewan standar akuntansi di Indonesia dalam hal ini Ikatan Akuntan Indonesia (IAI) telah melakukan antisipasi dengan cara, mengambil kebijakan untuk mengadopsi standar pelaporan keuangan yang sama dengan standar pelaporan keuangan yang banyak digunakan oleh negara-negara kawasan ASEAN. Standar pelaporan keuangan saat ini digunakan oleh rata-rata negara yang ada di kawasan ASEAN serta yang digunakan oleh banyak negara di dunia adalah Internasional Financial Reporting Standard (IFRS).

Gamayuni (2009) menjelaskan IFRS adalah suatu upaya untuk memperkuat arsitektur keuangan global dan mencari solusi jangka panjang terhadap kurangnya transparansi informasi keuangan. Masih menurut Gamayuni tujuan penerapan IFRS adalah memastikan bahwa laporan keuangan interim perusahaan untuk periode-periode yang dimasukkan dalam laporan keuangan tahunan, mengandung informasi berkualitas tinggi yang menghasilkan transparansi bagi para pengguna, dapat dibandingkan sepanjang periode yang disajikan, menyediakan titik awal yang memadai untuk akuntansi yang berdasarkan pada IFRS serta dapat dihasilkan dengan biaya yang tidak melebihi manfaat untuk para pengguna. 
Ball (2006), menjelaskan bahwa IFRS telah digunakan oleh lebih dari 150-an negara, diantaranya ada Jepang, China, Kanada dan negara-negara yang ada di Uni Eropa. Negaranegara yang lebih dahulu mengadopsi IFRS menunjukkan dampak positif terhadap laporan keuangannya, hal ini ditunjukkan dalam beberapa penelitian sebelumnya yang dilakukan di berbagai negara. Salah satunya Hung \& Subramanyam (2007), yang menguji dampak penerapan IFRS di Jerman, hasil penelitiannya menemukan bahwa laba perusahaan yang ditampilkan di laporan keuangan setelah mengadopsi IFRS lebih besar dari pada, jika menggunakan standar akuntansi nasionalnya. Indonesia sendiri telah mengkonvergensi standar akuntansi internasional ini yang ditetapkan oleh IAI. Konvergensi standar akuntansi internasional berarti menggabungkan atau mengintegrasikan standar akuntansi yang ada di setiap negara untuk diarahkan kedalam satu titik tujuan yaitu IFRS. Dengan adanya IFRS diharapkan nantinya dapat meningkatkan kualitas informasi akuntansi pada suatu perusahaan.

Bartov et al. (2005) menguji efek penggunaan IFRS terhadap kualitas informasi akuntansi pada perusahaan yang ada di Jerman. Hasil penelitian menunjukkan bahwa setelah adopsi IFRS, kualitas informasi akuntansi mengalami peningkatan ditandai dengan penurunan praktik manajemen laba dan relevansi nilai informasi akuntansi yang mengalami peningkatan.

Hung dan Subramanyam (2007) dalam penelitiannya menguji dampak pengadopsian IFRS terhadap kualitas informasi akuntansi pada perusahaan yang ada di Jerman selama tahun 1998-2002. Mereka menemukan bahwa tidak terdapat perbedaan dalam relevansi nilai dari angka-angka akuntansi setelah mengadopsi IFRS, tetapi ada bukti lemah yang menunjukkan bahwa laba berdasarkan IFRS menunjukkan konservatisme kondisional yang lebih besar daripada laba yang dihasilkan dari pelaporan berdasarkan standar akuntansi Jerman.

Dimitropoulos et al. (2013), menguji dampak konvergensi IFRS terhadap kualitas informasi akuntansi pada perusahaan yang ada di Yunani. Hasil penelitiannya menunjukkan implementasi IFRS dapat mengurangi manajemen laba, pengakuan kerugian lebih tepat waktu dan terdapat relevansi nilai yang lebih besar dibandingkan standar akuntansi lokal.

\section{Tinjauan Pustaka 2.1 Agency Theory}

Jensen dan Meckling (1976) mendefenisikan jika kedua kelompok (agent dan principal) tersebut adalah orang-orang yang berupaya memaksimalkan utilitasnya, maka terdapat alasan yang kuat untuk meyakini bahwa agent tidak akan selalu bertindak yang terbaik untuk kepentingan principal. Pemilik perusahaan sebagai pihak principal mengadakan kontrak untuk meningkatkan kesejahteraan dirinya dengan profitabilitas perusahaan yang selalu meningkat. Manajer sebagai agent termotivasi untuk meningkatkan pemenuhan kebutuhan ekonomi dan psikologisnya misalnya saja dalam hal memperoleh investasi, pinjaman, maupun kontrak kompensasi.

Sedangkan Scott (2000) berpendapat bahwa perusahaan mempunyai lebih dari satu kontrak. Sebagai contoh kontrak kerja antara perusahaan dengan para manajernya dan kontrak pinjaman antara perusahaan dangan krediturnya. Dimana antara agent dan principal ingin memaksimalkan utility masing-masing dengan informasi yang dimiliki. Akan tetapi biasanya, agent memiliki informasi yang lebih banyak (full information) dibandingkan dengan principal, sehingga menimbulkan asimetri informasi.

\subsection{Signaling Theory}

Wolk et al (2001) mengemukakan dimana teori sinyal menjelaskan alasan perlunya perusahaan menyajikan informasi untuk pihak eksternal perusahaan dan tentang bagaimana 
seharusnya sebuah perusahaan memberikan sinyal-sinyal kepada pengguna laporan keuangan. Teori sinyal terkait dengan adanya kesenjangan informasi antara manajemen perusahaan dan pihak-pihak yang berkepentingan dengan informasi tersebut. Biasanya manajemen perusahaan memiliki banyak informasi dibandingkan pihak eksternal perusahaan. Teori sinyal mengemukakan salah satu cara untuk mengurangi kesenjangan informasi adalah memberikan sinyal kepada pemakai informasi.

\subsection{Internasional Financial Reporting Standard (IFRS)}

Ball (2006) menjelaskan bahwa IFRS adalah standar akuntansi keuangan yang diterbitkan oleh International Accounting Standard Board (IASB), sebuah organisasi independen yang berada di London, UK. Tujuan organisasi ini yaitu untuk menciptakan seperangkat aturan pelaporan keuangan yang dapat diterima oleh perusahaan-perusahaan di dunia untuk memastikan bahwa perusahaan tersebut diterima secara global di pasar modal dunia. Sebelumnya, standar internasional diterbitkan pada tahun 1973-2000 oleh International Accounting Standard Committe (IASC). Pada perode ini standar IASC lebih dikenal dengan International Accounting Standard (IAS). Mulai april 2001, fungsi pembuatan standar dialihkan ke IASB yang baru dibentuk. IASB mengadopsi seluruh IAS dan memperkenalkan standar akuntansi baru dengan nama International Financial Reporting Standards (IFRS). IASB melanjutkan fungsi IASC dengan pendanaan yang lebih baik, staf yang lebih baik dan yang lebih independen dari pendahulunya yaitu IASC.

\subsection{Relevansi Nilai Informasi Akuntansi}

Francis dan Schipper (1999) mendefinisikan relevansi nilai informasi akuntansi sebagai kemampuan angka-angka akuntansi untuk merangkum informasi yang mendasari harga saham, sehingga relevansi nilai diindikasikan dengan sebuah hubungan statistikal antara informasi keuangan dengan harga atau return saham.

Barth et al. (2008) juga mengungkapkan pendapat serupa dengan yang disampaikan oleh Francis dan Schipper (1999), bahwa kualitas informasi akuntansi yang tinggi diindikasikan dengan adanya hubungan yang kuat antara harga/return saham dengan laba serta nilai buku ekuitas karena kedua informasi akuntansi tersebut mencerminkan kondisi ekonomik perusahaan Pengujian hubungan antara informasi akuntansi dengan nilai saham memerlukan suatu model penilaian.

Terdapat dua tipe model penilaian yang umumnya digunakan untuk menginvestigasi hubungan tersebut, yaitu model harga (price model) dan model return (return model). Kedua model tersebut diderivasi dari fondasi teoritis yang sama yaitu yang dikenal sebagai model informasi linier (linear information model) yang dikembangkan oleh Ohlson (1995).

Model Ohlson (1995) pada dasarnya menghubungkan nilai pasar perusahaan (harga saham) dengan laba dan nilai buku serta informasi lain yang dapat mempengaruhi relevansi nilai informasi akuntansi. Model penilaian ini diperlukan untuk membuktikan hubungan antara informasi akuntansi dengan harga atau perubahan harga saham. Secara umum, model Ohlson adalah sebagai berikut :

$P$ it $+1=\alpha_{0}+\alpha_{1} \mathbf{x}_{i t}+\alpha_{3} x_{i t}+\alpha_{4} v_{i t}+\epsilon_{i t}$

Keterangan:

Pit+1 = Harga saham perusahaan i pada 3 bulan setelah $\mathrm{t}$ 


$\begin{array}{ll}\boldsymbol{\alpha}_{1} \mathbf{x}_{\mathbf{i t}} & =\text { Earnings Per Share (EPS) } \\ \boldsymbol{\alpha}_{3} \mathbf{x}_{\mathbf{i t}} & =\text { Book Value of Equity Per Share (BVEPS) } \\ \boldsymbol{\alpha}_{\mathbf{4}} \boldsymbol{v}_{i t} & =\text { Informasi selain EPS dan BVEPS }\end{array}$

Kebanyakan penelitian mengenai relevansi nilai informasi akuntansi menggunakan $R^{2}$ dari model harga dan atau model return sebagai pengukur relevansi-nilai seperti yang dilakukan oleh Francis dan Schipper (1999) dan Lev dan Zarowin (1999). Hal ini disebabkan karena $R^{2}$ merupakan pengukur explanatory power dari variabel independen dalam suatu regresi linier.

Penelitian ini fokus untuk melihat perbedaan kualitas akrual dan relevansi nilai informasi akuntansi sebelum dan sesudah PSAK konvergensi IFRS pada perusahaan perbankan yang terdaftar di Bursa Efek Indonesia (BEI). Secaa sistematis kerangka pikir dapat digambarkan sebagai berikut:

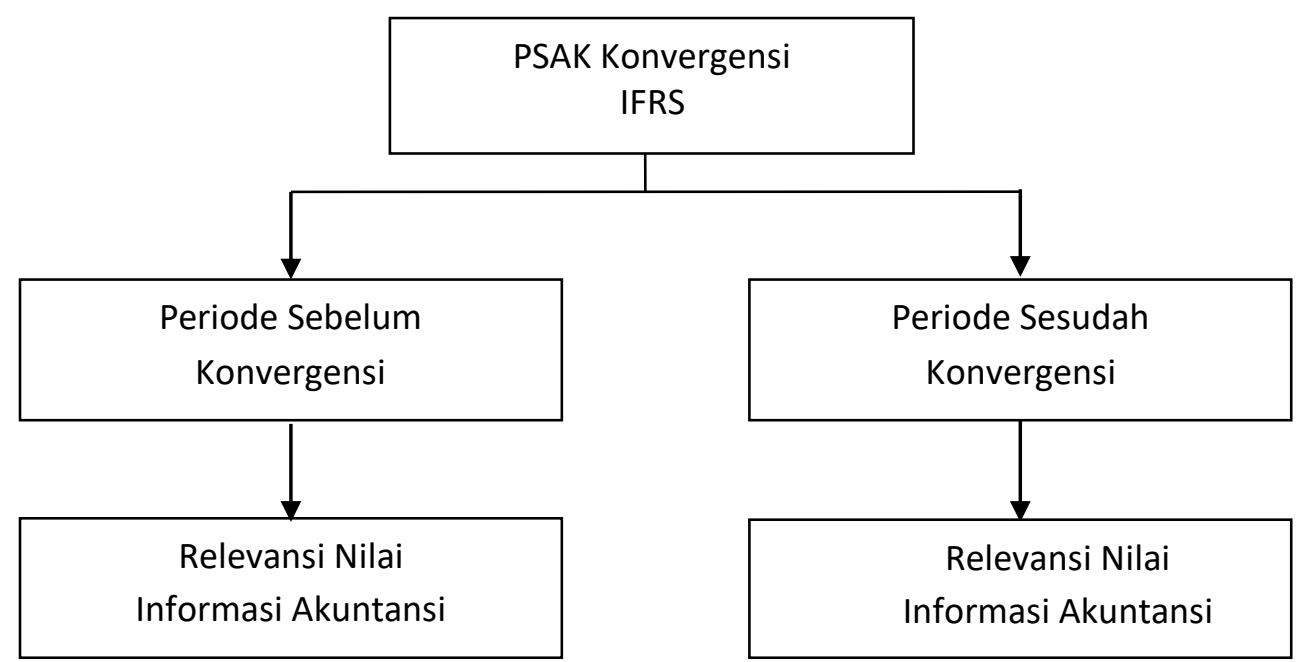

Gambar 1 : Kerangka Pemikiran Pengujian Hipotesis

\section{Methodologi Penelitian}

Penelitian ini merupakan studi empiris yang dilakukan dengan cara menganalisa data secara historis. Pengujian hipotesis untuk relevansi nilai informasi akuntansi dilakukan dengan uji t sampel berpasangan (paired-sample $t$ test). Uji ini dilakukan terhadap dua sampel yang berpasangan. Sampel yang berpasangan diartikan sebagai sebuah sampel dengan subjek yang sama, namun mengalami dua perlakuan atau pengukuran yang berbeda (Ghazali, 2012). Dalam penelitian ini, Paired-Sample T Test digunakan untuk menguji apakah terdapat perbedaan relevansi nilai informasi akuntansi antara periode sebelum dan sesudah konvergensi IFRS. Pengujian dilakukan terhadap komponen relevansi nilai yang dibagi menjadi dua kelompok sampel. Kelompok sampel 'sebelum' terdiri dari data tahun 2009-2011 sedangkan untuk kelompok sampel 'sesudah' terdiri dari data tahun 2012-2014.

Dengan demikian dapat ditarik suatu kesimpulan bahwa:

1) Jika probabilitas (sig t) $>(\alpha 0,05)$ artinya tidak ada perbedaan kualitas akrual serta relevansi nilai informasi akuntansi sebelum dan sesudah PSAK konveregensi IFRS.

2) Jika probabilitas (sig t) $<(\alpha 0,05)$ artinya ada perbedaan kualitas akrual serta relevansi nilai informasi akuntansi sebelum dan sesudah PSAK konveregensi IFRS. 


\section{Hasil dan Pembahasan}

Hasil uji ini bertujuan untuk melihat relevansi nilai informasi akuntansi sebelum dan sesudah PSAK konvergensi IFRS. Adapun hasil dari uji paired sample t-test ini adalah sebagai berikut.

Tabel 1: Uji T Sampel Berpasangan (Paired-Sample T Test) Paired Samples Test

\begin{tabular}{|c|c|c|c|c|c|c|c|c|c|}
\hline & & \multicolumn{5}{|c|}{ Paired Differences } & \multirow[b]{3}{*}{$t$} & \multirow[b]{3}{*}{$d f$} & \multirow[b]{3}{*}{ Sig. (2-tailed) } \\
\hline & & \multirow[b]{2}{*}{ Mean } & \multirow[b]{2}{*}{ Std. Deviation } & \multirow{2}{*}{$\begin{array}{l}\text { Std. Error } \\
\text { Mean }\end{array}$} & \multicolumn{2}{|c|}{$\begin{array}{l}95 \% \text { Confidence Interval of the } \\
\text { Difference }\end{array}$} & & & \\
\hline & & & & & Lower & Upper & & & \\
\hline Pair 1 & $\begin{array}{l}\text { Relevasi Nilai Sebelum } \\
\text { Konvergensi IFRS- } \\
\text { Relevasi Nilai Sesudah } \\
\text { Konvergensi IFRS }\end{array}$ & .011333 & .014742 & .008511 & -.025288 & .047955 & 1.895 & 113 & .014 \\
\hline
\end{tabular}

Sesuai dengan kriteria pengambilan keputusan untuk pengujian hipotesis, apabila nilai signifikan lebih kecil dari 0,05 (sig < 0,05) maka hipotesis diterima dan begitu sebaliknya jika signifikan lebih besar dari 0,05 (sig > 0,05) maka hipotesis di tolak. Berdasarkan tabel 1 di atas, dapat dilihat nilai signifikan yang dihasilkan adalah 0,014 . Nilai ini lebih kecil dari pada $\alpha 0,05$ (sig $0,013<\alpha 0,05$ ). Dari tabel di atas juga dapa dilihat bahwa $t_{\text {hitung }}<t_{\text {tabel }}$ yaitu 1,895>1,65845. Dari hasil dapat disimpulkan hipotesis diterima dimana artinya terdapat perbedaan relevansi nilai informasi akuntansi sebelum dan sesudah PSAK konvergensi IFRS pada perusahaan sektor perbankan yang terdaftar di Bursa Efek Indonesia tahun 2009 - 2014.

Hasil penelitian pada hipotesis 2 ini mendukung penelitian yang dilakukan di Inggris oleh Latridis (2010). Dimana secara umum kualitas informasi akuntansi di Inggris meningkat setelah mengadopsi IFRS jika dibandingkan dengan kualitas informasi akuntansi sebelum mengadopsi IFRS. Hal yang sama juga terdapat pada penelitian yang dilakukan oleh Bartov et al (2005), hasil penelitian mereka menemukan bahwa terdapat perbedaan kualitas informasi akuntansi sebelum dan sesudah pengadopsian IFRS pada perusahaan-perusahaan yang ada di Jerman.

Hasil penelitian ini juga sesuai dengan penelitian Chua et al (2012) yang menyatakan bahwa relevansi nilai informasi akuntansi semakin meningkat bila dibandingkan saat masih menggunakan standar domestik. Relevansi nilai ini semakin meningkat setelah dilakukan konvergensi IFRS karena sebagai principles-based standards dinilai lebih dapat meningkatkan relevansi nilai informasi akuntansi. Pengukuran dengan fair value lebih dapat menggambarkan posisi dan kinerja ekonomik perusahaan, sehingga laporan keuangan dikatakan lebih relevan. Hal ini dapat membantu investor dalam mengambil keputusan investasi secara tepat.

Sebaliknya penelitian ini bertentangan dengan penelitian yang dilakukan oleh Hung and Subramanyam (2007), mereka tidak menemukan perbedaan pada kualitas informasi akuntansi sebelum dan sesudah pengadopsian IFRS. Serta penelitian yang dilakukan oleh Cahyonowati dan Ratmono (2012), aplikasi standar berbasis IFRS di Indonesia belum dapat meningkatkan kualitas informasi akuntansi.

Temuan pada pada penelitian ini membuktikan ternyata tidak selamanya argumentasi yang disampaikan Karampinis dan Hevas (2011) dalam penelitiannya terbukti. Pada penelitian ini dengan diterapkannya PSAK konvergensi IFRS diperusahaan perbankan yang ada di Indonesia dapat meningkatkan relevansi nilai informasi akuntansi. Dimana dalam penelitian Karampinis dan Hevas tersebut menyatakan bahwa di negara-negara code law (termasuk Indonesia), dengan karakteristik lingkungan institusional seperti perlindungan investor yang lemah, kurangnya penegakan hukum, kepemilikan terkonsentrasi, dan pendanaan yang berorientasi pada perbankan maka adopsi IFRS belum tentu dapat meningkatkan relevansi nilai informasi akuntansi. 


\section{Kesimpulan}

Dari hasil penelitian dapat di simpulkan bahwa terdapat perbedaan relevansi nilai informasi akuntansi sebelum dan sesudah PSAK konvergensi IFRS pada perusahaan perbankan yang terdaftar di Bursa Efek Indonesia (BEI). Hal ini disebabkan karena salah satu karakteristik pada IFRS yang berbasis nilai wajar, yang dinilai lebih dapat meningkatkan relevansi nilai informasi akuntansi. Pengukuran dengan nilai wajar lebih dapat menggambarkan posisi dan kinerja ekonomik perusahaan, sehingga laporan keuangan dikatakan lebih relevan. Hal ini dapat membantu investor dalam mengambil keputusan investasi secara tepat.

\section{DAFTAR PUSTAKA}

1. Bakhri, Boy S. 2015. "Kesiapan Indonesia Menghadapi Masyarakat Ekonomi ASEAN 2015 Dari Perspektif Daya Saing Nasional”. Jurnal Ekonomi, Manajemen dan Akutansi I Vol. 25 No. 2 Desember 2015.

2. Ball, R. 2006. "International Financial Reporting Standards (IFRS): pros and cons for investor". Accounting and Bussines Research, International Accounting Forum : 5-27.

3. Barth, M. E,; Landsman, W. R. and Lang, M. 2008. "International Accounting Standards AND Accounting Quality". Journal of accounting research, 46, 467-498.

4. Bartov, E; Goldberg, S and Kim, M. 2005. "Comparative value relevance among German, US and International Accounting Standards: A German stock market perspective". Journal of Accounting Auditing \& Finance, vol. 20, no. 2, pp. 95-119.

5. Cahyonowati, Nur and Ratmono, Dwi. 2012. "Adopsi IFRS dan Relevansi Nilai Informasi Akuntansi." Jurnal Akuntansi Dan Keuangan, vol. 14, no. 2, November 2012: 105-115

6. Chua, E. Y. L,; C. S. Cheong, and G. Gould. 2012. "The impact of mandatory IFRS adoption on accounting quality: Evidence from Australia." Journal of International Accounting Research.

7. Dimitropoulos, E.Panagiotis,; Dimitrios Asteriou,; Dimitrios Kousenidis and Stergios Leventis. 2013. "The Impact of IFRS on accounting quality: Evidence from Greece". Advances in accounting incorporating Advances in International Accounting no.29, pp 108-123.

8. Francis, J. and Schipper, K. 1999. "Have financial Statement Lost Their Relevance?". Journal Of Accounting Research, 37, 319-352.

9. Gamayuni, Rindu. 2009. "Perkembangan Standar Akuntansi Keuangan Indonesia Menuju International Financial Reporting Standards". Jurnal Ilmiah Berkala Enam Bulanan ISSN 1410 - 1831,Vol.14, No.2.

10. Ghozali, Imam. 2012. "Aplikasi Analisis Multivariate Dengan Program SPSS". Semarang: Badan Penerbit Universitas Dipenogoro.

11. Hung, M. and Subramayam, K.R. 2007. "Financial statement effects of adopting international accounting standards, the case of germany". Review of accounting standards, 12, 623-657.

12. Jensen, Michael C. and W.H Meckling. 1976. "Theory Of the Firm: Managerial Behavior, Agency Cost and Ownership Structure”. Journal of Financial ekonomics 3:305360 .

13. Karampini, N and Hevas, D. 2011. "Mendating IFRS in an Unfavorable Environment: The Greek Experience”. The International journal of Accounting, 46, 304-332. 
14. Latridis, George. 2010. "International Financial Reporting Standards and the quality financial statements information". International Review of Financial Analysis, 19 193204.

15. Lev, Baruch and zarowin, Paul. 1999. "the Boundaries of Financial Reporting and How to Extend Them”. Journal of Accounting Research, Vol. 37, 353-385.

16. Ohlson, J. 1995. "Earnings, Book Values, and Devidends in Quality Valuations". Contemporary Accounting Research, 11, 661-688.

17. Scott, R.W.. 2006. "Financial accounting theory". (7th edition), Pearson education, Toronto, Canada.

18. Wolk, I. Harry; Michael G. Tearney and James L. Dodd. 2001. "Accounting Conceptual and Institutional Approach”. 5ed, South-Western College Publishing. 